University of Nebraska - Lincoln

DigitalCommons@University of Nebraska - Lincoln

4-2012

\title{
Synchrony of net nitrogen mineralization and maize nitrogen uptake following applications of composted and fresh swine manure in the Midwest U.S.
}

\author{
Terrance D. Loecke \\ University of Nebraska-Lincoln, tloecke2@unl.edu \\ Cynthia A. Cambardella \\ National Soil Tilth Laboratory ARS-USDA, Ames, IA, cindy.cambardella@ars.usda.gov \\ Matt Liebman \\ lowa State University, mliebman@iastate.edu
}

Follow this and additional works at: https://digitalcommons.unl.edu/natrespapers

Loecke, Terrance D.; Cambardella, Cynthia A.; and Liebman, Matt, "Synchrony of net nitrogen

mineralization and maize nitrogen uptake following applications of composted and fresh swine manure in the Midwest U.S." (2012). Papers in Natural Resources. 376.

https://digitalcommons.unl.edu/natrespapers/376

This Article is brought to you for free and open access by the Natural Resources, School of at DigitalCommons@University of Nebraska - Lincoln. It has been accepted for inclusion in Papers in Natural Resources by an authorized administrator of DigitalCommons@University of Nebraska - Lincoln. 


\title{
Synchrony of net nitrogen mineralization and maize nitrogen uptake following applications of composted and fresh swine manure in the Midwest U.S.
}

\author{
Terrance D. Loecke • Cynthia A. Cambardella • \\ Matt Liebman
}

Received: 27 April 2011/Accepted: 14 April 2012/Published online: 26 April 2012

(C) Springer Science+Business Media B.V. 2012

This article is a U.S. government work, and is not subject to copyright in the United States.

\begin{abstract}
Understanding how the quality of organic soil amendments affects the synchrony of nitrogen (N) mineralization and plant $\mathrm{N}$ uptake is critical for optimal agronomic $\mathrm{N}$ management and environmental protection. Composting solid livestock manures prior to soil application has been promoted to increase $\mathrm{N}$ synchrony; however, few field tests of this concept have been documented. Two years of replicated field trials were conducted near Boone, Iowa to determine the effect of composted versus fresh solid swine manure (a mixture of crop residue and swine urine and feces produced in hoop structures) on Zea mays (maize) $\mathrm{N}$ uptake, in situ soil net $\mathrm{N}$ mineralization, and soil inorganic $\mathrm{N}$ dynamics. Soil applications of composted manure increased maize $\mathrm{N}$ accumulation
\end{abstract}

Electronic supplementary material The online version of this article (doi:10.1007/s10705-012-9500-6) contains supplementary material, which is available to authorized users.

T. D. Loecke · C. A. Cambardella · M. Liebman Department of Agronomy, Iowa State University, Ames, IA 50011, USA

T. D. Loecke ( $\square)$

School of Natural Resources, University of NebraskaLincoln, 616 Hardin Hall, 3310 Holdrege St, Lincoln, NE 68583-0996, USA

e-mail: tloecke2@unl.edu

C. A. Cambardella

National Soil Tilth Laboratory ARS-USDA,

Ames, IA 50011, USA by $25 \%$ in 2000 and $21 \%$ in 2001 compared with fresh manure applications (application rate of $340 \mathrm{~kg} \mathrm{~N} \mathrm{ha}^{-1}$ ). Despite significant differences in net $\mathrm{N}$ mineralization between years, within year seasonal total in situ net $\mathrm{N}$ mineralization was similar for composted and fresh manure applications. Partial $\mathrm{N}$ budgets indicated that changes in soil $\mathrm{N}$ pools (net $\mathrm{N}$ mineralization and soil inorganic $\mathrm{N}$ ) in the surface $20 \mathrm{~cm}$ accounted for $67 \%$ of the total plant $\mathrm{N}$ accumulation in 2000 but only $16 \%$ in 2001 . Interannual variation in maize $\mathrm{N}$ accumulation could not be attributed to soil $\mathrm{N}$ availability. Overall, our results suggest that composting manures prior to soil application has no clear benefit for $\mathrm{N}$ synchrony in maize crops. Further work is required to determine the biotic and abiotic factors underlying this result.

Keywords Asynchrony · Corn · Midwest - Soil fertility $\cdot$ Manure management

\section{Introduction}

Nitrogen is the soil nutrient most commonly limiting crop productivity in temperate agroecosystems (Dahlin et al. 2005). To alleviate crop $\mathrm{N}$ deficiency, management strategies are deployed to increase the supply of soil inorganic-N (SIN, mainly $\mathrm{NO}_{3}{ }^{-}$and $\mathrm{NH}_{4}{ }^{+}$) that is available for plant uptake. However, when SIN exceeds immediate plant and soil microbial assimilation capacity, SIN is vulnerable to be lost from 
agricultural systems via hydrologic (e.g., $\mathrm{NO}_{3}{ }^{-}$ leaching) and gaseous (e.g., denitrification and $\mathrm{NH}_{3}$ volatilization) pathways. Hydrologic transport of $\mathrm{NO}_{3}{ }^{-}$and $\mathrm{NH}_{4}{ }^{+}$from agricultural systems can lead to the degradation of surface and groundwater resources (Bohlke 2002; Rabalais et al. 2001; Smolder et al. 2010). Gaseous emissions of reactive $\mathrm{N}$ compounds (e.g., ammonia, nitric oxides, and nitrous oxide) can cause eutrophication and acidification of aquatic and terrestrial ecosystems, impair tropospheric air quality, degrade stratospheric ozone, and contribute to the radiative forcing of the atmosphere (Holland and Lamarque 1997; Vitousek et al. 1997; IPCC 2007). Furthermore, loss of SIN represents an economic inefficiency of production agriculture. In contrast, insufficient SIN availability leads to yield loss and inefficient allocation of other agricultural inputs (e.g., other fertilizers, pesticides, and seed).

The goal of agricultural $\mathrm{N}$ management is to maximize crop yield while minimizing $\mathrm{N}$ loss to the environment by temporal coupling of SIN supply with crop N demand (i.e., $\mathrm{N}$ synchrony) (Crews and Peoples 2005). The main components of $\mathrm{N}$ synchrony are: (1) soil net $\mathrm{N}$ mineralization (the sum of the conversion of organic-N to SIN and the immobilization of SIN into soil microbial biomass); (2) SIN available for crop uptake; (3) crop N uptake. Typically 50-100 \% of crop $\mathrm{N}$ uptake is derived from SIN recently mineralized from organic-N sources (i.e., soil organic matter, organic amendments, and plant residue) (Robertson 1997). Improved understanding of how soil management and organic amendment application influence $\mathrm{N}$ mineralization is critical for optimizing $\mathrm{N}$ synchrony, but few studies to date have simultaneously measured the different components of $\mathrm{N}$ synchrony.

Soil $\mathrm{N}$ mineralization and immobilization are tightly regulated by the relative demand for organic$\mathrm{C}$ and $\mathrm{N}$ by soil microbes (Hadas et al. 1996). The addition of labile-C to soil stimulates soil heterotroph population growth and assimilation of SIN (i.e., $\mathrm{N}$ immobilization). As labile-C becomes exhausted, soil heterotroph populations decline in part due to predation from higher trophic levels (Clarholm 1985). Following predator ingestion, the microbial biomass$\mathrm{N}$ exceeds the $\mathrm{N}$ assimilation capacity of the predators and $\mathrm{NH}_{4}{ }^{+}$is excreted into the soil solution (i.e., $\mathrm{N}$ mineralized). The resulting $\mathrm{N}$ immobilization and $\mathrm{N}$ mineralization follow first order kinetics. The balance of these two processes, net $\mathrm{N}$ mineralization, commonly displays an initial rapid $\mathrm{N}$ mineralization or $\mathrm{N}$ immobilization phase upon soil application followed by a linear mineralization phase (Honeycutt et al. 1994). The duration and magnitude of the initial phase is largely attributable to the $\mathrm{C}: \mathrm{N}$ of the soil amendment. Soil application of high $\mathrm{C}: \mathrm{N}$ organic matter (e.g., Avena sativa straw) leads to longer-term and greater immobilization than material with a lower $\mathrm{C}: \mathrm{N}$. Soil application of an amendment with a C:N of 20 or less is not expected to immobilize $\mathrm{N}$ during the initial phase of decomposition.

Nitrogen synchrony can be improved by applying amendments low in C:N if peak SIN supply is expected to occur after crop $\mathrm{N}$ demand or amendments with elevated C: $\mathrm{N}$ if $\mathrm{N}$ loss prior to crop $\mathrm{N}$ demand is likely to occur. Composting organic matter under aerobic conditions prior to soil application is one possible approach to reduce the labile organic matter content and $\mathrm{C}: \mathrm{N}$ of soil amendments. Composted plant material and animal manure has long been used to improve soil fertility, although in practice composting can have mixed effects on net $\mathrm{N}$ mineralization (Cambardella et al. 2003; Shi et al. 1999). In recent years, deepbedded swine production systems have gained popularity in the Midwest region of the United States (e.g., hoop-house swine production) (Honeyman et al. 2001). These systems periodically add A. sativa straw or maize stalks as bedding for the swine and at the end of a production cycle the bedding/manure mixture is removed. This mixture can be applied immediately to agricultural fields or be piled nearby for composting. Composting of this mixture has the benefit of reducing the volume of material needed to apply to fields; however, it also tends to lose in $\mathrm{C}$ and $\mathrm{N}$ at a similar rate (Cambardella et al. 2003). To date, little is known about the influence of composting deep-bedded swine manure on $\mathrm{N}$ synchrony.

Testing the effects of amendment quality on $\mathrm{N}$ synchrony is currently data limited (e.g., Brinton 1985; Brye et al. 2003; Karlen et al. 1987). To address this knowledge gap we tested the general hypothesis that soil application of composted manure results in improved synchrony between soil $\mathrm{N}$ supply and plant $\mathrm{N}$ demand over the application of fresh manure. Specifically, we compared the effects of spring soil application of composted versus fresh solid swine manure on temporal patterns of in situ net $\mathrm{N}$ mineralization and SIN relative to maize $\mathrm{N}$ uptake across two growing seasons. 


\section{Materials and methods}

This experiment was conducted on adjacent fields during 2000 and 2001 at the Iowa State University's Agronomy and Agricultural Engineering Research Farm near Boone, Iowa $\left(42^{\circ} 01^{\prime} \mathrm{N}, 93^{\circ} 45^{\prime} \mathrm{W}\right)$. Mean annual temperature for the site is $8.9^{\circ} \mathrm{C}$ and mean annual precipitation is $876 \mathrm{~mm}$. Both field sites were in a soybean (Glycine max L.)-maize-oat rotation with no animal manure application within the previous 10 year. The soil of the 2000 site was a Nicollet loam (fine-loamy, mixed, superactive, mesic, Aquic Hapludolls), whereas the 2001 site was mainly a Webster silty clay loam (fine-loamy, mixed, superactive, mesic, Typic Endoaquolls). Pre-treatment soil tests of each field indicated sufficient plant available $\mathrm{P}$ and $\mathrm{K}$ for maize production. Details of this field experiment are also given in a publication describing maize growth responses to composted versus fresh swine manure (Loecke et al. 2004a).

The amendments used in this experiment were produced in a deep-bedded (maize stalks used as bedding) swine finishing unit, known as a hoop house (Honeyman et al. 2001). In November of each year prior to soil application, composted manure was produced by placing fresh hoop house manure into a composting windrow $(2 \mathrm{~m}$ in height $\times 3 \mathrm{~m}$ in width $\times 10 \mathrm{~m}$ in length) and mixing the compost on four dates with a windrow turner. Manures were obtained from the Iowa State University Rhodes Research Farm in Marshall County, Iowa, except for the fresh manure applied in the spring of 2001, which was from a commercial farm in Story County, Iowa. In all cases the fresh manure and compost used in this experiment came from different batches of fresh manure.

Experimental plots were laid out in a randomized complete block design with four replicates. Plots consisted of five maize rows spaced $0.76 \mathrm{~m}$ apart and were $61 \mathrm{~m}$ in length in 2000 and $73 \mathrm{~m}$ in 2001. On 21 Apr 2000 and 24 Apr 2001, fresh and composted hoop manures were applied at a rate of $340 \mathrm{~kg}$ of total $\mathrm{N} \mathrm{ha}{ }^{-1}$. This rate was based on the assumption that approximately one-third of the total $\mathrm{N}$ (i.e. $110 \mathrm{~kg} \mathrm{~N} \mathrm{ha}^{-1}$ ) would be plant-available in the first year after application (Eghball and Power 1999; Loecke et al. 2004b). The dry weight bulk application rate of composted manure was $29 \mathrm{Mg} \mathrm{ha}^{-1}$ in 2000 and $20 \mathrm{Mg} \mathrm{ha}^{-1}$ in 2001 and for fresh manure it was
$16 \mathrm{Mg} \mathrm{ha}^{-1}$ in 2000 and $18 \mathrm{Mg} \mathrm{ha}^{-1}$ in 2001. Amendments were applied using a rear-discharge spreader that had been calibrated for each amendment each year. Within $6 \mathrm{~h}$ of application the amendments were incorporated into the surface $15 \mathrm{~cm}$ of soil with a disk. In 2000, two passes with a culti-packer were also necessary for seedbed preparation due to dry soil conditions. Amendment characteristics were determined from 4-L composite samples collected from twenty $0.18-\mathrm{m}^{2}$ plastic trays placed inside the spreader path within each plot at the time of application. Amendment samples were immediately stored on ice in the field and then stored at $-20{ }^{\circ} \mathrm{C}$, thawed to $2{ }^{\circ} \mathrm{C}$ for $<6 \mathrm{~h}$ to homogenize and subsample for various analyses (total $\mathrm{C}, \mathrm{N}, \mathrm{P}, \mathrm{K}, \mathrm{NH}_{4}{ }^{+}, \mathrm{NO}_{3}{ }^{-}$, moisture, and ash concentration, $\mathrm{pH}$, and electrical conductivity), and then refrozen until individual variables were analyzed. Analytical methods for amendment characterization are detailed in Loecke et al. (2004a) and a chemical and physical characterization of the amendments is reprinted with permission in Table 1. Soil bulk density was unaffected by amendment treatments in either year, averaging $1.25 \mathrm{Mg} \mathrm{m}^{-3}$ on the dates measured (4 May 2000 and 9 May 2001).

\section{Plant nitrogen accumulation}

Aboveground maize plants were harvested from the center three rows of each plot 13 times in 2000 and 11 times in 2001. Plant harvests began on 22 May 2000 (18 days after planting) and 6 Jun 2001 (29 days after planting) and finished on 7 Sept 2000 and 19 Sept 2001. All replicates were harvested within $4 \mathrm{~h}$ of each other on all harvest dates. At seedling emergence, each plot was divided into subplots and randomly assigned repeated harvests for aboveground biomass, grain yield, and $\mathrm{N}$ concentration determination. Subplots consisted of four equally spaced plants (7.1 plants $\mathrm{m}^{-2}$ ) and three subplots per plot were harvested every 7-16 days until physiological maturity. Aboveground biomass was dried at $60{ }^{\circ} \mathrm{C}$ in paper bags for a minimum of 4 days and weighed. Starting at the onset of the reproduction growth phase, the dry weight was determined by subsampling after determining the total wet weight. Aboveground plant tissue $\mathrm{N}$ concentration was determined by Kjeldahl digestion (Harris Laboratory, Lincoln, NE) on samples ground to pass a 0.85 $\mathrm{mm}$ screen. Insufficient subsampling of biomass from four harvest dates during 2000 from day of year (DOY) 
Table 1 Selected chemical characteristics of composted and fresh swine manures applied in 2000 and 2001, near Boone, IA

\begin{tabular}{|c|c|c|c|c|}
\hline \multirow[t]{2}{*}{ Amendment parameters } & \multicolumn{2}{|l|}{2000} & \multicolumn{2}{|l|}{2001} \\
\hline & Compost & Fresh & Compost & Fresh \\
\hline Ash $\left(\mathrm{g} \mathrm{kg}^{-1}\right)$ & $714(8)$ & 439 (113) & $594(14)$ & $434(8)$ \\
\hline $\mathrm{C}\left(\mathrm{g} \mathrm{kg}^{-1}\right)$ & $129(6)$ & $254(22)$ & $201(17)$ & $243(25)$ \\
\hline $\mathrm{N}\left(\mathrm{g} \mathrm{kg}^{-1}\right)$ & $11.7(0.4)$ & $21.0(2.3)$ & $16.4(1.2)$ & $18.3(0.8)$ \\
\hline$P\left(\mathrm{~g} \mathrm{~kg}^{-1}\right)$ & $8.7(0.2)$ & $9.7(1.0)$ & $6.3(1.5)$ & $9.2(0.8)$ \\
\hline $\mathrm{K}\left(\mathrm{g} \mathrm{kg}^{-1}\right)$ & $15.4(0.2)$ & $21.5(0.7)$ & $15.5(2.6)$ & $16.7(0.9)$ \\
\hline $\mathrm{NH}_{4}{ }^{+}-\mathrm{N}\left(\mu \mathrm{g} \mathrm{g}^{-1}\right)$ & $1,108(584)$ & $4,980(1867)$ & $596(80)$ & $2,003(135)$ \\
\hline $\mathrm{NO}_{3}-\mathrm{N}\left(\mu \mathrm{g} \mathrm{g}^{-1}\right)$ & $546(168)$ & $75(42)$ & $59(28)$ & $47(20)$ \\
\hline $\mathrm{C}: \mathrm{N}$ & $11.0(0.2)$ & $12.3(2.1)$ & $12.3(0.2)$ & $13.3(1.0)$ \\
\hline $\mathrm{pH}$ & $8.1(0.2)$ & $8.4(0.3)$ & $8.6(0.04)$ & $8.4(0.08)$ \\
\hline $\mathrm{EC}(\mathrm{mS})$ & $5,600(715)$ & $5,114(796)$ & $3,693(270)$ & $2,942(824)$ \\
\hline
\end{tabular}

Amendment parameters are presented as the mean of four samples \pm 1 standard error

Table reprinted from Loecke et al. (2004a) with permission

195-250 led to a loss of representative samples for total $\mathrm{N}$ concentration determination during this period.

Soil inorganic $\mathrm{N}$ pools and fluxes

Net soil $\mathrm{N}$ mineralization rates were determined in situ using a modified buried bag method (Eno 1960). In this method, two adjacent soil cores (diameter $3.2 \mathrm{~cm}$ ) were simultaneously taken to a depth of $20 \mathrm{~cm}$. The surface $20 \mathrm{~cm}$ of soil is the most likely soil depth to be influenced by the application of amendments; however, this does not capture the whole depth of the maize rooting zone. One core was removed from the field and analyzed for SIN and moisture. The second core was placed intact into a polyethylene bag (0.019$\mathrm{mm}$, thickness), sealed, return to the hole from where it came, and retrieved approximately 14 days later. As the second sample was retrieved, another pair of soil cores was taken, and the entire process was repeated. Three bags per plot were used to determine plot level mineralization during each incubation period. The first cores of each season were taken on 5 May 2000 and 14 May 2001, the day of planting and 5 days after planting in 2000 and 2001, respectively. A total of 13 in situ incubations were conducted during 2000 and 11 during 2001. This process was repeated until 3 Nov 2000 and 17 Oct 2001, except for a 6 days break at grain harvest (DOY 252-258) in 2000. Cores were taken from random locations within the plots $12-15 \mathrm{~cm}$ from the maize row in the inter-row area. All soils were kept cool $\left(\sim 4{ }^{\circ} \mathrm{C}\right)$ and subsampled for moisture and SIN analyses within $24 \mathrm{~h}$ of field sampling.

Soil samples were sieved (8-mm) and subsampled for SIN and moisture content. Soil inorganic $\mathrm{N}\left(\mathrm{NO}_{2}{ }^{-}\right.$, $\mathrm{NO}_{3}{ }^{-}$, and $\mathrm{NH}_{4}{ }^{+}$) was extracted by mixing $10 \mathrm{~g}$ of soil with $50 \mathrm{~mL}$ of $2 \mathrm{M} \mathrm{KCl}$ and shaking for $30 \mathrm{~min}$ before filtering (Keeney and Nelson 1987). The filtrate was stored at $-10{ }^{\circ} \mathrm{C}$ until analyzed by Lachat flow analysis (Lachat Instruments, Milwaukee, WI). Soil moisture content was determined gravimetrically after oven drying a subsample $(15-20 \mathrm{~g})$ for $24 \mathrm{~h}$ at $105^{\circ} \mathrm{C}$. Bulk density was determined on samples taken during the first sampling of each year. All SIN and mineralization data are presented on an area basis by correcting for the bulk density. Net $\mathrm{N}$ mineralization $(\mathrm{NMinN})$ was calculated where:

$\mathrm{N} \min \mathrm{N}=\mathrm{SIN}_{\mathrm{n}+1}-\mathrm{SIN}_{\mathrm{n}}$

$\mathrm{n}$ is the in situ incubation interval. Cumulative NminN at time $\mathrm{t}$ is the sum of $\mathrm{NminN}$ at $\mathrm{t}=\mathrm{n}$ and $\mathrm{t}=\mathrm{n}+1$.

To examine the synchrony of in situ $\mathrm{N}$ mineralization and plant $\mathrm{N}$ accumulation we estimated whole plant $\mathrm{N}$ accumulation (above- and belowground). First, the aboveground biomass for each harvest was multiplied by published root to shoot ratios to estimate belowground maize root biomass. Second, maize root $\mathrm{N}$ content throughout the growing season was derived by multiplying published maize root $\mathrm{N}$ concentrations by maize root biomass. The estimated maize root $\mathrm{N}$ content was then added to the measured aboveground $\mathrm{N}$ content for a whole plant $\mathrm{N}$ content estimate at each 
harvest. The in situ incubation periods and maize biomass harvests were not conducted on the same dates. To place both plant and soil $\mathrm{N}$ dynamics on the same time frame we used a linear interpolation method to estimate the plant $\mathrm{N}$ uptake rates on the same time scale as each in situ incubation period.

We calculated total root biomass using Amos and Walters' (2006) function for maize root to shoot ratios that were derived from 41 published studies. The function estimates root:shoot ratios for maize throughout the growing season where:

$\mathrm{R}: \mathrm{S}=\mathrm{a}+\mathrm{b} * \mathrm{e}^{\mathrm{k} * \mathrm{DAE}}$

$\mathrm{R}: \mathrm{S}$ is the estimated root to shoot dry biomass ratio, $a+b$ is the R:S at emergence, $b$ is the R:S approached at the end of the growing season, $\mathrm{k}$ is the rate constant and DAE is the days after plant emergence. The parameter and standard errors estimates we used to predict $R: S$ were: $\mathrm{a}=0.15 \pm 0.05, \mathrm{~b}=0.53 \pm 0.05$, $\mathrm{k}=-0.03 \pm 0.008$ as presented in Amos and Walters (2006).

We used maize root $\mathrm{N}$ concentration data from Sanchez et al. (2002) and Johnson et al. (2007)to derive a maize $\operatorname{root} \mathrm{N}$ function where $\mathrm{N}$ concentration of maize root biomass declined linearly with time after plant emergence, where:

$\mathrm{R}_{\mathrm{N}}=\mathrm{a} * \mathrm{DAP}+\mathrm{b}$

$\mathrm{R}_{\mathrm{N}}$ is the maize root $\mathrm{N}$ concentration $\left(\mathrm{mg} \mathrm{N} \mathrm{kg}^{-1}\right)$ throughout the growing season, a is the rate of concentration change, $\mathrm{b}$ is the initial root $\mathrm{N}$ concentration, and DAP is the days after planting. The parameter and standard error estimates we used are $\mathrm{a}=-0.009 \pm 0.0045$ and $\mathrm{b}=2 \pm 0.5$

\section{Statistical analysis}

Uncertainty in root $\mathrm{N}$ content estimates was propagated according probability theory ( $\mathrm{Li}$ and $\mathrm{Wu} 2006$ ). Repeated measures analysis of variance (ANOVA) was conducted by PROC MIXED routine in SAS with residual maximum likelihood estimations (Littell et al. 2005) to test for main and interactive effects of sampling date and manure application. A heterogeneous autoregressive covariance structure was selected to model the among sampling date variance for each of the repeated measures ANOVA using Akaike's criteria (Akaike 1974). This allowed for individual sampling date main effect comparisons using independent error variance estimations for each date. Soil inorganic N content data were natural $\log$ transformed to meet homogeneity of variance assumptions of ANOVA. Comparisons were considered significant at the $P \leq 0.05$ level. Between year comparisons were conducted on the final plant $\mathrm{N}$ content using ANOVA with manure and year as the main effects; block effects were nested within years. Where significant treatment by harvest or sampling date interaction effects occurred, years were analyzed separately. $T$ tests were used to determine significance of $\mathrm{N}$ budget differences for each budget period. Pearson's correlations were conducted with the ProcCorr routine in SAS (Littell et al. 2005). Means presented in the text are followed by \pm 1 standard error.

\section{Results}

Total seasonal cumulative $\mathrm{N}$ fluxes

Data from the two growing seasons are presented separately due to the large differences in weather conditions and soil and plant responses to the soil amendments. The spring and early summer of 2000 were drier than normal, but had average air temperatures (data presented in Loecke et al. 2004a). Soil moisture content in 2000 ranged from 0.12 to $0.19 \mathrm{~g}$ $\mathrm{H}_{2} \mathrm{O} g$ soil $^{-1}$ and averaged $0.16 \mathrm{~g} \mathrm{H}_{2} \mathrm{Og}$ soil $^{-1}$ (Fig. 1). In 2001, the soil moisture averaged $0.17 \mathrm{~g}$ $\mathrm{H}_{2} \mathrm{O}$ g soil $^{-1}$ and ranged from 0.13 to $0.21 \mathrm{~g} \mathrm{H}_{2} \mathrm{O} \mathrm{g}$ soil $^{-1}$. Soil amendments affected soil moisture content similarly throughout both seasons.

Soil inorganic $\mathrm{N}$ content was similar in soils amended with composted and fresh manures throughout 2000 except for two sampling dates when the compost-amended soils exceeded fresh manureamended soils (Fig. 2). The trend of higher SIN from compost during the first month following amendment application corresponded to significant differences in cumulative soil net $\mathrm{N}$ mineralization between the amendments. During this time soils amended with compost only immobilized SIN during the first 2-4 weeks whereas fresh manure-treated soils immobilized net quantities of $\mathrm{N}$ until ca. 9 weeks following application (Fig. 2). Despite excess SIN available in the surface $20 \mathrm{~cm}$ of soil early in the 2000 growing season in both treatments, maize grown in compostamended soils accumulated more aboveground $\mathrm{N}$ in 


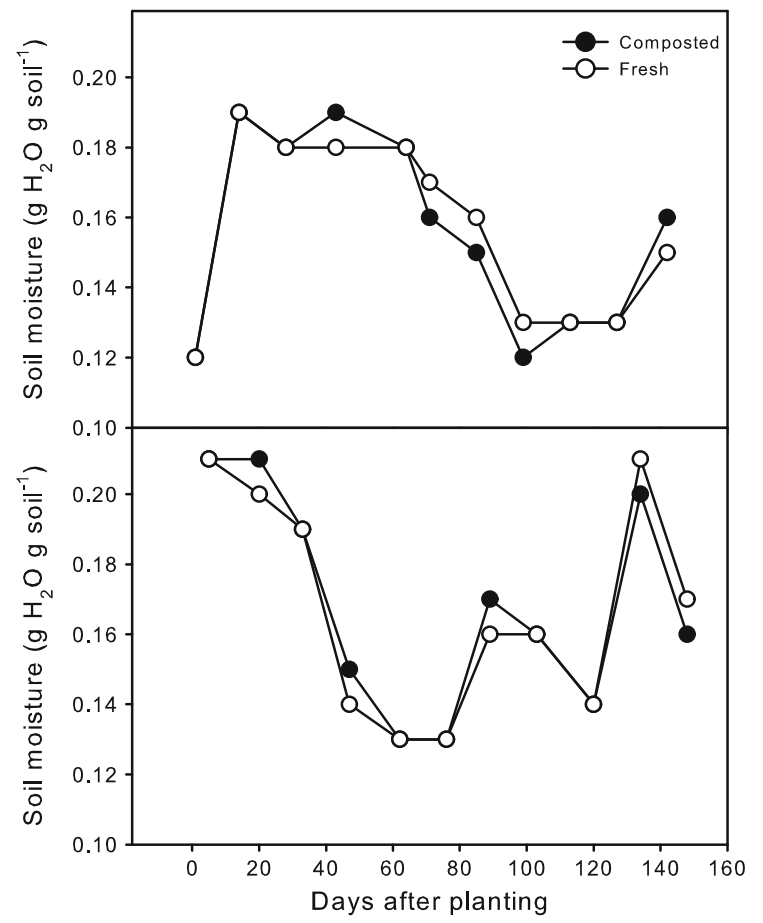

Fig. 1 Moisture content of the surface $20 \mathrm{~cm}$ of soil during the 2000 and 2001 growing seasons, near Boone, Iowa, USA

the first few weeks of growth than maize subjected to fresh manure amendments (Fig. 2). This treatment difference in $\mathrm{N}$ uptake persisted throughout the 2000 growing season and resulted in compost treated maize accumulating $25 \%$ more aboveground $\mathrm{N}$ than maize in fresh manure-amended soil (218 vs. $174 \pm$ $11 \mathrm{~kg} \mathrm{~N} \mathrm{ha}^{-1}$ ). In contrast, similar end of the season aboveground biomass resulted from the compost and fresh manure applications (Fig. 1 supplemental materials). By maize harvest in 2000, net $\mathrm{N}$ mineralization had largely stopped and no cumulative treatment differences were detected. On average $62 \pm$ $26 \mathrm{~kg} \mathrm{~N} \mathrm{ha}^{-1}$ were mineralized throughout the 2000 season in the amended soils. Likewise, soil inorganic $\mathrm{N}$ pools in the surface $20 \mathrm{~cm}$ of soil were similar between amendment treatments averaging $19 \pm$ $4 \mathrm{~kg} \mathrm{~N} \mathrm{ha}^{-1}$ prior to soil freezing conditions (DOY 294).

In contrast to the wide range of SIN in 2000, SIN varied little in 2001 ranging from 9 to $29 \mathrm{~kg} \mathrm{~N} \mathrm{ha}^{-1}$ across the amended soils (Fig. 2). Limited variation was also observed in in situ net $\mathrm{N}$ mineralization rates throughout 2001. Nevertheless, fresh manureamended soils mineralized significantly more SIN than compost amended soils during the first 5 of 6 mineralization periods (10 of 12 weeks) (Fig. 2). The total accumulated mineralized $\mathrm{N}$ during the 2001 in situ incubations was similar in compost and fresh manure-amended soils averaging $12 \mathrm{~kg} \mathrm{~N}^{-1} \pm 13$, which was not detectably different from zero. This indicates that no net $\mathrm{N}$ mineralization was measured in compost or fresh manure-amended soils in 2001. At physiological maturity in 2001, maize grown in compost-amended soils accumulated $21 \%$ more $\mathrm{N}$ (184 vs. $152 \pm 14 \mathrm{~kg} \mathrm{~N} \mathrm{ha}^{-1}$ ) (Fig. 2) and $12.3 \%$ more biomass (18.2 vs. $16.2 \pm 0.8 \mathrm{Mg} \mathrm{ha}^{-1}$ ) (Fig. 1 supplemental materials) than fresh manure-amended soils. No statistical difference was observed in aboveground biomass between years (Fig. 1 supplemental materials).

Net growing season changes in SIN, in situ mineralized $\mathrm{N}$, and whole plant $\mathrm{N}$ accumulation were used to construct partial $\mathrm{N}$ budget for each growing season. Soil inorganic $\mathrm{N}$ decreased from an initial maximum of $80-11 \mathrm{~kg} \mathrm{~N}^{-1}$ for a $69 \mathrm{~kg} \mathrm{~N} \mathrm{ha}^{-1}$ difference over 126 days (DOY 126-252) during 2000 and changed by $15 \mathrm{~kg} \mathrm{~N}^{-1}$ from 29 to $14 \mathrm{~kg}$ $\mathrm{N} \mathrm{ha}^{-1}$ as the 2001 season progressed. As mentioned above, net $\mathrm{N}$ mineralization was similar for each treatment in each year with $62 \mathrm{~kg} \mathrm{~N}^{-1}$ mineralizing in 2000 and $12 \mathrm{~kg} \mathrm{~N}^{-1}$ in 2001. Partial $\mathrm{N}$ budgets indicated that total seasonal changes in soil $\mathrm{N}$ pools (net $\mathrm{N}$ mineralization and soil inorganic $\mathrm{N}$ ) in the surface $20 \mathrm{~cm}$ accounted for $67 \%[(62+69) /$ 196] of the total plant $\mathrm{N}$ accumulation in 2000 but only $16 \%[(12+15) / 164]$ in 2001 .

\section{Nitrogen synchrony}

To examine the synchrony of total plant $\mathrm{N}$ uptake (total $=$ aboveground content plus belowground $\mathrm{N}$ content estimate) and net $\mathrm{N}$ mineralization rates we constructed a partial $\mathrm{N}$ budget for each in situ incubation period. The daily $\mathrm{N}$ budget is presented such that positive flux differences indicate greater plant $\mathrm{N}$ uptake than net $\mathrm{N}$ mineralization, neutral flux differences indicate synchrony, and negative flux differences suggest greater $\mathrm{N}$ mineralization than plant $\mathrm{N}$ uptake (Fig. 3). The daily $\mathrm{N}$ flux differences varied from -0.8 to $3.6 \mathrm{~kg} \mathrm{~N}^{-1} \mathrm{day}^{-1}$ in 2000 and -0.5 to $2.6 \mathrm{~kg} \mathrm{~N} \mathrm{ha}^{-1} \mathrm{day}^{-1}$ in 2001 . In 2000, the average daily flux difference was 0.92 and $0.94 \mathrm{~kg} \mathrm{~N} \mathrm{ha}^{-1} \mathrm{day}^{-1}$ for compost and fresh manure 
Fig. 2 Above ground plant $\mathrm{N}$ accumulation (top two panels), cumulative in situ mineralized $\mathrm{N}$ (middle to panels), and soil inorganic $\mathrm{N}$ $\left(\mathrm{NO}_{3}{ }^{-}\right.$and $\mathrm{NH}_{4}{ }^{+}$, surface $20 \mathrm{~cm}$ of soil) (lower two panels) in response to spring application of composted and fresh manure during 2000 and 2001, Boone, Iowa. The data from 2000 are presented in panels in the left column and from 2001 in panels in the right column. Error bars represent \pm 1 SE. Asterisks indicates significance differences for a sampling date $(P<0.05)$

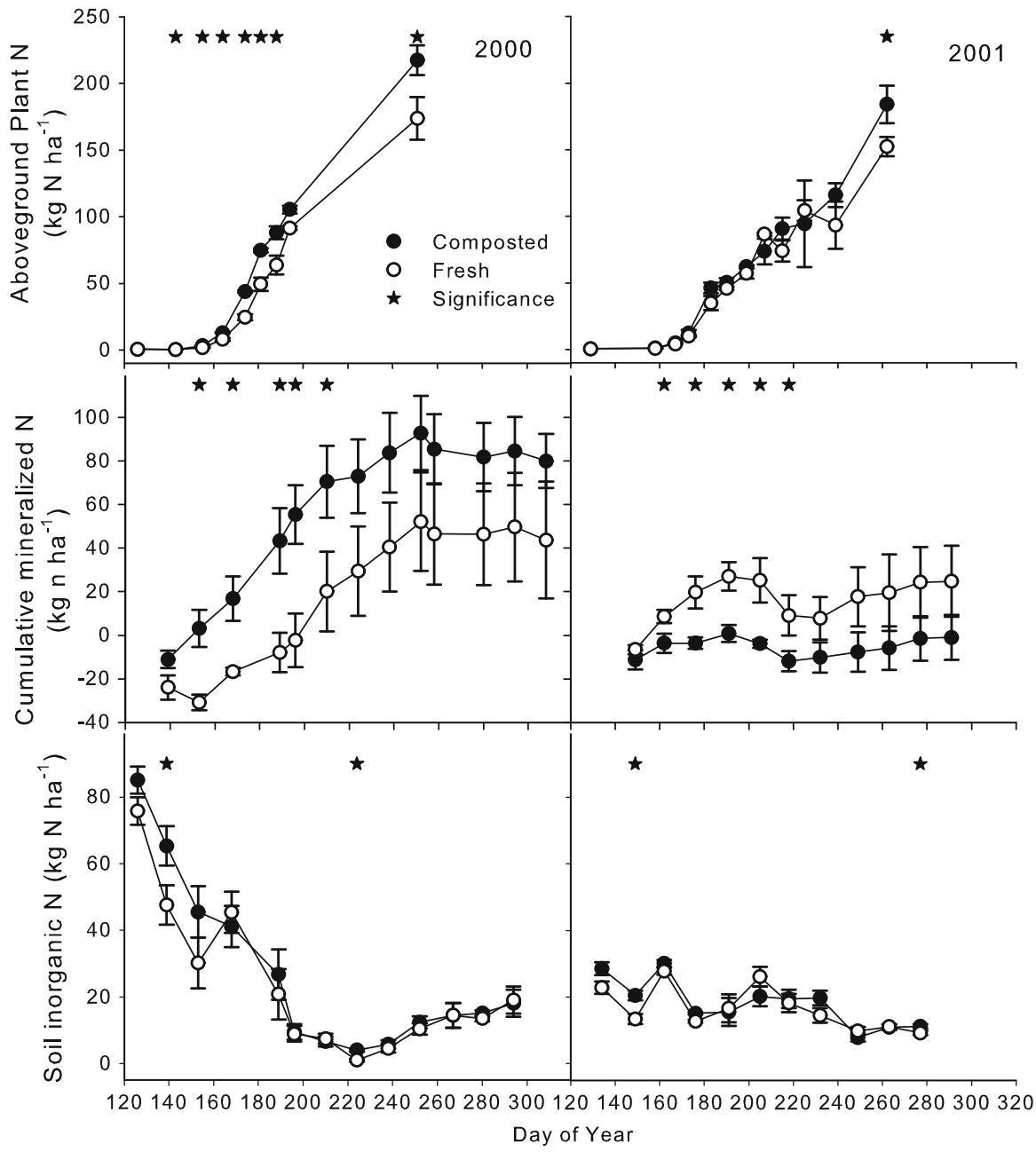

applications, respectively, whereas in 2001, the average daily flux difference was 1.30 and $0.93 \mathrm{~kg} \mathrm{~N} \mathrm{ha}^{-1}$ day $^{-1}$ from compost and fresh manure applications, respectively. This indicates on average greater plant $\mathrm{N}$ uptake than soil $\mathrm{N}$ mineralization from both treatments in both years. In 2000, composted manure-amended soils produced $\mathrm{N}$ asynchrony during seven in situ incubation periods; whereas fresh manure-amended soils were asynchronous during four periods (Fig. 3). In contrast, during 2001 asynchrony was only detectable during two in situ incubation periods, both of which were in response to fresh manure-treated soils.

\section{Discussion}

We found partial support for the hypothesis that soil application of composted solid swine manure produces greater synchrony between soil net $\mathrm{N}$ mineralization and plant $\mathrm{N}$ uptake than from soil application of fresh solid swine manure. Net $\mathrm{N}$ mineralization results from the first year (2000) qualitatively follow predicted first-order kinetics (Honeycutt et al. 1991). However, the 2001 net $\mathrm{N}$ mineralization patterns were surprisingly stagnate (Fig. 2). Other reports of net $\mathrm{N}$ mineralization following soil application of composted and fresh livestock manures indicate variable inter-annual responses (Ma et al. 1999b but see Eghball 2000). Annual and seasonal variation of environmental conditions during the composting process and following soil application (e.g., soil temperature and moisture) have previously been invoked to explain the inter-annual differences among these studies (e.g., Ma et al. 1999b), but the connection between environmental conditions and soil $\mathrm{N}$ dynamics is less clear for our study. 


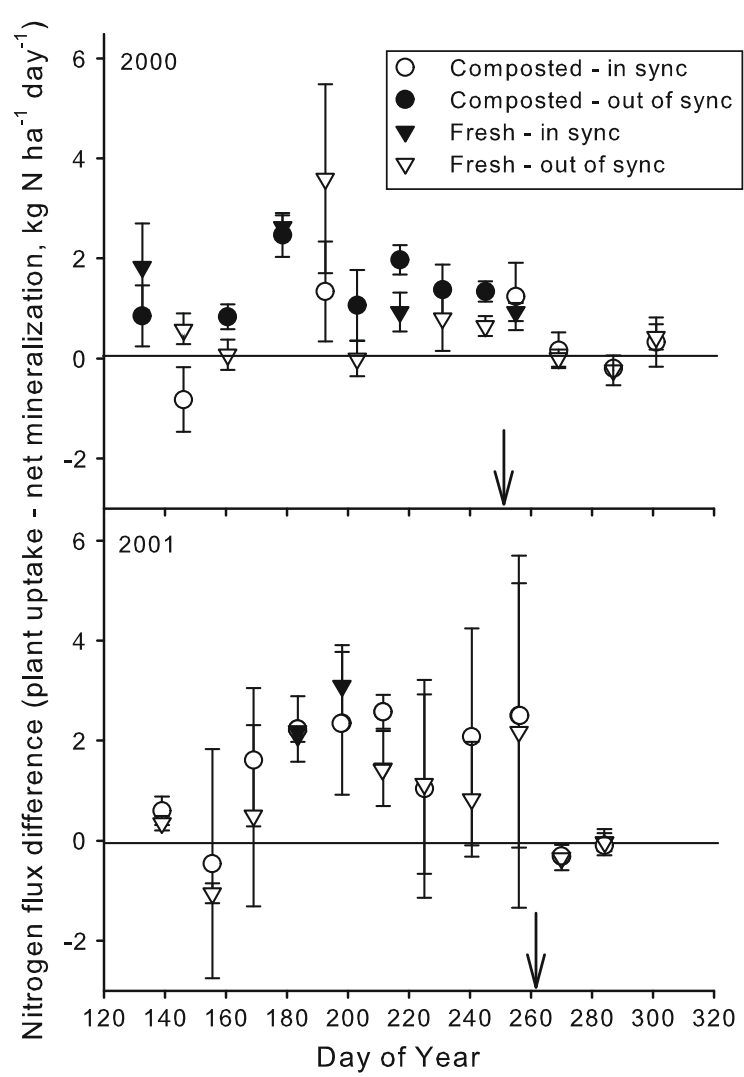

Fig. 3 The difference between plant $\mathrm{N}$ accumulation and net $\mathrm{N}$ mineralization during each in situ incubation period for composted (circles) and fresh (triangles) swine manure during 2000 and 2001, near Boone, Iowa. Solid symbols represent significant differences from a synchronous $\mathrm{N}$ budget and open symbols represent no significant differences from a balanced $\mathrm{N}$ budget. A positive difference indicates greater soil inorganic $\mathrm{N}$ consumption than mineralization, no difference indicates $\mathrm{N}$ synchrony, and a negative difference indicates greater soil $\mathrm{N}$ mineralization than plant $\mathrm{N}$ uptake. The arrows represent final maize harvest of each season

The combination of dry weather conditions that limit the potential for anion leaching below the surface soil and rapid nitrification likely explain the elevated SIN in soils amended with both fresh and composted swine manure in the spring of 2000 (Fig. 2). However, it is important to note that no differences in SIN were observed during the first soil sampling following amendment application. During in situ incubations of the first year of our study, soil moisture content in the in situ incubation bags was positively correlated with net $\mathrm{N}$ mineralization rates $(\mathrm{r}=0.35, P>0.01)$. In contrast, in 2001 there was no detectable relationship between soil moisture and net $\mathrm{N}$ mineralization rates and on average the soil was more moist in 2001 $\left(0.172 \mathrm{~g} \mathrm{H}_{2} \mathrm{O} \mathrm{g} \mathrm{soil}{ }^{-1}\right)$ than in $2000\left(0.167 \mathrm{~g} \mathrm{H}_{2} \mathrm{O} \mathrm{g}\right.$ soil $^{-1}$ ) (Fig. 1) with similar variability $(\mathrm{CV}=0.03$ for both year). This may suggest that soil moisture differences between the 2 years were not an important factor driving the large inter-annual differences in net $\mathrm{N}$ mineralization; however, a longer-term dataset would be required to eliminate variation in soil moisture as a causal mechanism. Despite only having 2 years of data, given the positive relationship between soil moisture and net $\mathrm{N}$ mineralization in 2000 we would have expected greater mineral $\mathrm{N}$ accumulation in the more moist soil of 2001 than 2000; however, the opposite effect was observed.

The chemical and physical properties of the fresh manures were similar between years, although the compost had higher ash content in 2000 than in 2001 (Table 1). Greater ash content indicates more soil incorporated into the windrow during the composting process or greater degradation of the compost in 2000 than in 2001. This resulted in lower total C and $\mathrm{N}$ concentrations and a higher bulk application rate (29 $\mathrm{Mg} \mathrm{ha}^{-1}$ in 2000 vs. $20 \mathrm{Mg} \mathrm{ha}^{-1}$ in 2001) given the total $\mathrm{N}$ basis for determining the application rate. Consequently the $\mathrm{C}: \mathrm{N}$ of compost applications was significantly higher $(+11 \%)$ in 2001 compared with 2000, and there was an increase in the total $\mathrm{C}$ applied as compost (3.7 vs. $4.1 \mathrm{Mg} \mathrm{C}^{-1}$ in 2000 and 2001, respectively). Carbon to $\mathrm{N}$ ratios of less than 20 are generally expected to induce minimal short-term net $\mathrm{N}$ immobilization into soil microbial biomass (Mathur et al. 1993), so it is unlikely that differences in C:N between the compost applied in 2000 and 2001 can explain the large difference in soil $\mathrm{N}$ dynamics between years. The contrast in $\mathrm{NH}_{4}{ }^{+}: \mathrm{NO}_{3}{ }^{-}$between our composted and fresh manure amendments applied in 2000 ( 2 and 66, respectively) was more distinct than in 2001 (10 and 43, respectively) (Table 1). Higher amendment $\mathrm{NH}_{4}{ }^{+}: \mathrm{NO}_{3}{ }^{-}$are indicative of a less mature compost (i.e., more labile organic-C) and associated with a greater likelihood for initial $\mathrm{N}$ immobilization following soil incorporation (Mathur et al. 1993). In 2000, the difference between composted and fresh manure in this characteristic may partially explain why the compost did not immobilize as much SIN as the fresh manure following soil application in 2000. Whilst both amendments had lower inorganic $\mathrm{N}$ concentrations in 2001 compared with 2000 , it seems unlikely that these differences 
between years in amendment quality should dampen net $\mathrm{N}$ mineralization to the extent that we observed in 2001.

Despite the inconsistent soil $\mathrm{N}$ responses to the amendment treatments, compost-amended soils produced a similar maize $\mathrm{N}$ uptake advantage over fresh manure-treated soils in each year $(+25$ and $+21 \%$ in 2000 and 2001, respectively). Our results contrast with the lack of maize $\mathrm{N}$ uptake responses observed to composted and fresh beef cattle manure in Nebraska (Eghball and Power 1999) and stockpiled and rotted dairy manure in Ontario, Canada (Ma et al. 1999a). Our study differs from those mentioned above (Eghball and Power 1999; Ma et al. 1999a) in that this is the only compost versus fresh manure trial using solid swine manure instead of beef or dairy manure and this may have influenced $\mathrm{N}$ mineralization rate and responses to environmental conditions (e.g., soil moisture).

Notably, the point in each season when maize $\mathrm{N}$ uptake was detectably greater for composted than fresh manure treatments did not correspond to SIN differences that we would have predicted to influence plant growth. In the first year, maize $\mathrm{N}$ accumulation differences were first observed early in the season when SIN was available far in excess of plant demand in both treatments. In the second year, plant $\mathrm{N}$ differences were observed only at the end of the season when neither SIN nor net $\mathrm{N}$ mineralization rates suggested treatment differences in the surface soils. From these two observations we conclude that the plant $\mathrm{N}$ uptake treatment differences were not due to $\mathrm{N}$ availability in the surface $20 \mathrm{~cm}$ of soil or at least not directly.

The partial $\mathrm{N}$ budget indicated that plant $\mathrm{N}$ uptake (aboveground actual and belowground estimated) exceeded surface soil $(0-20 \mathrm{~cm})$ cumulative net $\mathrm{N}$ mineralization and SIN depletion by $81 \mathrm{~kg} \mathrm{~N} \mathrm{ha}^{-1}$ in 2000 and $165 \mathrm{~kg} \mathrm{~N} \mathrm{ha}^{-1}$ in 2001 (Fig. 3). Observations of plant $\mathrm{N}$ uptake in excess of soil $\mathrm{N}$ mineralization and SIN depletion are common in agricultural systems (e.g., Ma et al. 1999b; Sanchez et al. 2002). In our experiment, plant $\mathrm{N}$ uptake during peak demand ( $\sim$ DOY 170-240) may have been partially derived from deeper soil depths (Asbjornsen et al. 2008) and spatially rare but N-rich microsites (Wang and Bakken 1997) that elicit preferential maize root proliferation (Loecke and Robertson 2009). Alternatively, we may have underestimated the plant available soil $\mathrm{N}$ pools in the surface $20 \mathrm{~cm}$ (Sanchez et al. 2002). One such underestimation could be derived from $\mathrm{N}$ immobilization (i.e., microbial $\mathrm{N}$ assimilation) or denitrification induced when maize roots were excised from the plant while sampling to place soil cores into the polyethylene bags for in situ mineralization determination (Brye et al. 2002). This possibility was likely minimized during the 2000 season because the soil $\mathrm{N}$ mineralization rates did not decrease as maize root $\mathrm{C}: \mathrm{N}$ and biomass likely increased (Fig. 2). In contrast during 2001, moist soil conditions following planting (Fig. 1) may have encouraged root growth in the surface soil early in the season. This excised root tissue would have supported greater $\mathrm{N}$ immobilization and artificially reduced the $\mathrm{N}$ mineralization estimate.

Variability in the in situ $\mathrm{N}$ mineralization data and uncertainty in estimating the maize root $\mathrm{N}$ content resulted in poor statistical power for separating synchronous from asynchronous $\mathrm{N}$ dynamics. Further work is needed on soil $\mathrm{N}$ dynamics associated with mineralization measurement techniques and crop root $\mathrm{N}$ content to reduce this variability and advance our understanding of the controls on $\mathrm{N}$ use efficiency in agroecosystems.

Acknowledgments We would like to thank to Jody Ohmacht, Jay Berkey, Dave Sundberg, and Rhonda Graeffor their invaluable assistance in the field and laboratory. This research was supported by Chamness Technology Inc. and the Leopold Center for Sustainable Agriculture. We also thank two reviewers for thoughtful comments and suggestions.

\section{References}

Akaike H (1974) New look at statistical-model identification. IEEE Trans Autom Control 19:716-723

Amos B, Walters DT (2006) Maize root biomass and net rhizo deposited carbon: an analysis of the literature. Soil Sci Soc Am J 70:1489-1503

Asbjornsen H, Shepherd G, Helmers M, Mora G (2008) Seasonal patterns in depth of water uptake under contrasting annual and perennial systems in the Corn Belt Region of the Midwestern U.S. Plant Soil 308:69-92

Bohlke JK (2002) Groundwater recharge and agricultural contamination. Hydrogeol J 10:153-179

Brinton WF (1985) Nitrogen response of maize to fresh and composted manure. Biol Agric Hortic 3:55-64

Brye KR, Norman JM, Nordheim EV, Gower ST, Bundy LG (2002) Refinements to an in situ soil core technique for measuring net nitrogen mineralization in moist, fertilized agricultural soil. Agron J 94:864-869 
Brye KR, Norman JM, Gower ST, Bundy LG (2003) Effects of management practices on annual net $\mathrm{N}$-mineralization in a restored prairie and maize agroecosystems. Biogeochem 63:135-160

Cambardella CA, Richard TL, Russell A (2003) Compost mineralization in soil as a function of composting process conditions. Eur J Soil Biol 39:117-127

Clarholm M (1985) Interactions of bacteria, protozoa and plant leading to mineralization of soil nitrogen. Soil Bio Biochem 17:181-187

Crews TE, Peoples MB (2005) Can the synchrony of nitrogen supply and crop demand be improved in legume and fertilizer-based agroecosystems? A review. Nutr Cycl Agroecosys 72:101-120

Dahlin S, Kirchmann H, Katterer T, Gunnarsson S, Bergstrom L (2005) Possibilities for improving nitrogen use from organic materials in agricultural cropping systems. Ambio 34:288-295

Eghball B (2000) Nitrogen mineralization from field-applied beef cattle feedlot manure or compost. Soil Sci Soc Am J 64:2024-2030

Eghball B, Power JF (1999) Composted and noncomposted manure application to conventional and no-tillage systems: corn yield and nitrogen uptake. Agron J 91:819-825

Eno CF (1960) Nitrate production in the field by incubating the soil in polyethylene bags. Soil Sci Soc Am J 24:277-279

Hadas A, Kautsky L, Portnoy R (1996) Mineralization of composted manure and microbial dynamics in soil as affected by long-term nitrogen management. Soil Biol Biochem 28:733-738

Holland EA, Lamarque JF (1997) Modeling bio-atmospheric coupling of the nitrogen cycle through NOx emissions and NOy deposition. Nutr Cycl Agroecosys 48:7-24

Honeycutt CW, Potaro LJ, Halteman WA (1991) Predicting nitrate formation from soil, fertilizer, crop residue, and sludge with thermal units. J Environ Qual 20:850-856

Honeycutt CW, Clapham WM, Leach SS (1994) A functional approach to efficient nitrogen use in crop production. Ecol Mod 73:51-61

Honeyman, Harmon JD, Kliebenstein JB, Richard TL (2001) Feasibility of hoop structures for market swine in Iowa: pig performance, pig environment, and budget analysis. Appl Eng Agric 17:869-874

IPCC (2007) Climate Change 2007: the physical science basis. Contribution of working group I. In: Solomon S et al (eds) Fourth assessment report of the intergovernmental panal on climate change. Cambridge University Press, New York

Johnson JMF, Barbour NW, Weyers SL (2007) Chemical composition of crop biomass impacts its decomposition. Soil Sci Soc Am J 71:155-162

Karlen DL, Sadler EJ, Camp CR (1987) Dry matter, nitrogen, phosphorus, and potassium accumulation rates by corn on Norfolk loamy sand. Agron J 79:649-656

Keeney DR, Nelson DW (1987) Nitrogen-inorganic forms, sec. 33-3, extraction of exchangeable ammonium, nitrate, and nitrite. In: Page et al. (ed) Methods of soil analysis: part 2, chemical and microbiological properties, vol 9. Soil Sci Soc Am, Madison, WI, USA, pp 648-649

Li H, Wu J (2006) Uncertainty analysis in ecological studies: an overview. In: Wu J, Jones KB, Li H, Loucks OL (eds) Scaling and uncertainty analysis in ecology: methods and applications. Springer Press, The Netherlands, p 54

Littell RC, Milliken GA, Stroup WW, Wolfinger RD, Schabenberger O (2005) SAS for mixed models, 2nd edn. SAS Institute Inc, Cary

Loecke TD, Robertson GP (2009) Soil resource heterogeneity in the form of aggregated litter alters maize productivity. Plant Soil 325:231-241

Loecke TD, Liebman M, Cambardella CA, Richard TL (2004a) Corn growth responses to composted and fresh solid swine manures. Crop Sci 44:177-184

Loecke TD, Liebman M, Cambardella CA, Richard TL (2004b) Corn response to composting and time of application of solid swine manure. Agron J 96:214-223

Ma BL, Dwyer LM, Gregorich EG (1999a) Soil nitrogen amendment effects on nitrogen uptake and yield of maize. Agron J 91:650-656

Ma BL, Dwyer LM, Gregorich EG (1999b) Soil nitrogen amendment effects on seasonal nitrogen mineralization and nitrogen cycling in maize production. Agron $\mathrm{J}$ 91:1003-1009

Mathur SP, Owen G, Dinel H, Schnitzer M (1993) Determination of compost biomaturity: I. Literature review. Biol Agric Hortic 10:65-85

Rabalais NN, Turner RE, Wiseman WJ (2001) Hypoxia in the Gulf of Mexico. J Environ Qual 30:320-329

Robertson GP (1997) Nitrogen use efficiency in row-crop agriculture: crop nitrogen use and soil nitrogen loss. In: Jackson L (ed) Ecology in agriculture. Academic Press, New York, pp 347-365

Sanchez JE, Paul EA, Smeenk J (2002) Corn root effects on the nitrogen-supplying capacity of a conditioned soil. Agron J 94:391-396

Shi W, Norton JM, Miller BE, Pace MG (1999) Effects of aeration and moisture during windrow composting on the nitrogen fertilizer values of dairy waste composts. Appl Soil Ecol 11:17-28

Smolder AJP, Lucassen ECHET, Bobbink R, Roelofs JGM, Lamers LPM (2010) How nitrate leaching from agricultural lands provides phosphate eutrophication in groundwater fed wetlands: the sulphur bridge. Biogeochem 98:1-7

Vitousek PM, Aber JD, Howarth RW, Likens GE, Matson PA, Schindler DW, Schlesinger WH, Tilman DG (1997) Human alteration of the global nitrogen cycle: sources and consequences. Eco App 7:737-750

Wang JG, Bakken LR (1997) Competition for nitrogen during decomposition of plant residues in soil: effect of spatial placement of N-rich and N-poor plant residues. Soil Bio Biochem 29:153-162 


\section{Supplementary Material}

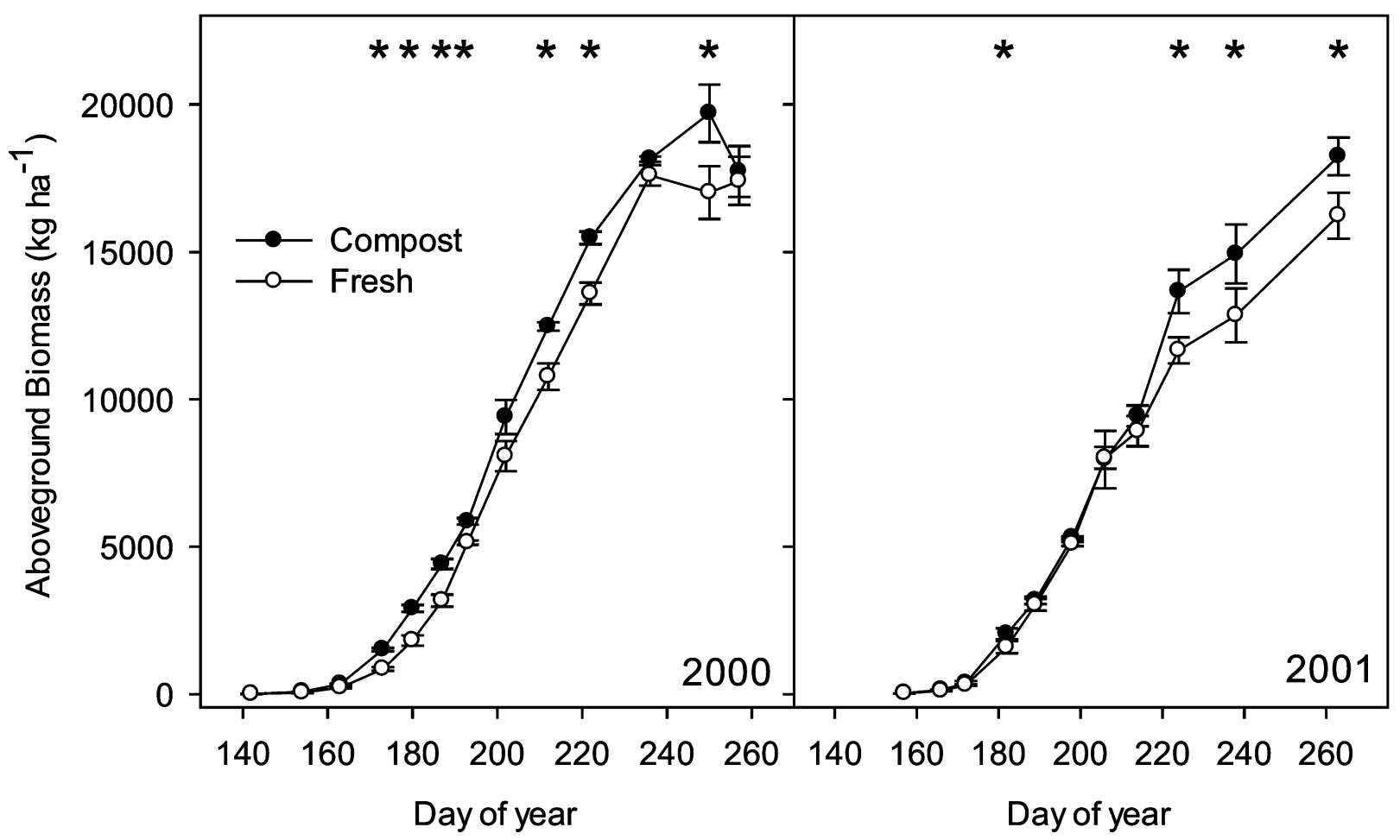

Fig. 1. Aboveground maize biomass accumulation in response to spring application of composted and fresh manure during 2000 and 2001, Boone, Iowa. The data from 2000 are presented in panels in the left column and from 2001 in panels in the right column. Error bars represent \pm 1 s.e. ${ }^{*}$ indicates significance differences for a sampling date $(\mathrm{P}<$ $0.05)$. 